\title{
Kamu Üniversite Sanayi İşbirliği ve Bölgesel Kalkınma-TR82 Bölgesi Örneği"
}

\author{
Hasan DAĞLAR \\ Çankırl Karatekin Üniversitesi, İktisadi ve İdari Bilimler Fakültesi, \\ hdaglar@karatekin.edu.tr
}

\begin{abstract}
Öz
Bu çalışmanın amacı; kamu üniversite sanayi işbirliği çalışmalarını incelemek ve bu çalışmaların bölgesel kalkınmayla olan ilişkilerini araştırmaktır. Bu çalışma; TR82 bölgesindeki Çankırı, Kastamonu ve Sinop illerindeki kamu üniversite sanayi işbirliğini ve bunun bölgesel kalkınmaya etkilerini kapsamaktadır. Çalışmanın yöntemi; TR82 bölgesindeki bölgesel kalkınma ajansı, üniversiteler, ticaret ve sanayi odaları, bilim sanayi ve teknoloji il müdürlüklerinin kamuya açık kaynaklarından yararlanarak mevcut durumu ve önerileri tespit etmektir. Kuzey Anadolu Kalkınma Ajansı'nın olduğu TR82 Bölgesinde üniversite sanayi işbirliğine dönük gayretler vardır. Bu illerdeki üniversitelerin öğrenci sayıları, akademik ve idari personelleri ile bölgesel kalkınmaya büyük katkı sağladığı söylenebilir. Kamu üniversite sanayi işbirliği çalışmaları sonrasında, bölgedeki öğretim elemanı sayısında önemli artış olduğu ve bölgedeki işsizlik oranlarının Türkiye seviyesinin oldukça altında kaldığı tespit edilmiştir.
\end{abstract}

Anahtar Kelimeler: Üniversite Sanayi İşbirliği, Kalkınma Ajansı, Bölgesel Kalkınma

JEL Sınıflandırma Kodları: M14, O18

Public University Industry Cooperation and Regional Development - TR82 Region Example ${ }^{\dagger}$

\begin{abstract}
This study aims to examine the studies about public university industry cooperation and the relations with regional development. This study covers public university industry cooperation and its effects on regional development in the TR82 region which includes Çankır1, Kastamonu and Sinop. Procedures and methods; To determine the current situation and recommendations by utilizing public open sources of universities, regional development agency, chambers of commerce and industry and science industry and technology provincial directorates in TR82 region. There are efforts for university industry cooperation in the region TR82 where the North Anatolian Development Agency operates. It can be said that the universities in these provinces have contributed greatly to the development of the region with the number of students, academic and administrative staff. There has been determined an increase academic staff number and the unemployment rate in the region found to be below the Turkey level after public universityindustry cooperation activities.

Key Words: University- Industry Cooperation, Development Agency, Regional Development.

JEL Classification Codes: M14, O18

\footnotetext{
* $\mathrm{Bu}$ makale, 21.05. 2015 tarihinde "4th International Vocational Schools Symposium " unda sözlü bildiri olarak sunulan ve özeti yayınlanan "Üniversite Sanayi İşbirliğinin Meslek Yüksekokulları Açısından Bölgesel Kalkınmaya Etkileri-TR82 Bölgesi Örneği” başlıklı bildiriden yararlanılarak hazırlanmıştır.

${ }^{\dagger}$ Extended abstract is presented at the end of the article.
}

\section{Atıfta bulunmak için/Cite this paper:}

Dağlar, H. (2018). Kamu üniversite sanayi işbirliği ve bölgesel kalkınma-Tr82 bölgesi örneği. Çankırı Karatekin Üniversitesi IIIBF Dergisi. 8 (2), 305-329. 


\section{Giriş}

Kalkınma, bir ülkedeki veya bölgedeki "salt üretimin ve kişi başına gelirin artırılması demek olmayıp, az gelişmiş bir toplumda iktisadi ve sosyo-kültürel yapının değiştirilmesi ve yenileştirilmesidir. Kişi başına düşen milli gelirin artması yanında, genel olarak üretim faktörlerinin etkinlik ve miktarlarının değişmesi, sanayi kesiminin milli gelir ve ihracat içindeki payının artması gibi yapısal değişiklikler, kalkınmanın temel öğeleridir.” (Han ve Kaya, 2012, s. 2)

Bir ülkenin kalkınması, ekonomisinin geliştirilmesi ve güçlendirilmesi, kişi başına düşen mili gelirin artırılması, üretim altyapısının geliştirilmesi ve insan kaynaklarının niteliklerinin artırılmasıdır. Her ülkede az ya da çok ama mutlaka bölgeler arasında ekonomik dengesizlikler görülmektedir.

Bölgesel dengesizliklere, yer altı ve yer üstü zenginlikler, doğal şartlar, iklim, ulaşım ve haberleşme imkânları gibi coğrafi nedenler yol açabilir. Ayrıca sosyoekonomik, tarihsel, kültürel nedenler de bölgeler arasında dengesizliklere yol açabilir. (Arı, 2006, s. 23)

"Ülkeler, bölgelerdeki mevcut kaynakları ve ortaya çıkarılmayan potansiyeli değerlendirip, gelişmeyi onlar üzerine inşa etmek, bölgelerin yeni güçlü yanlarını geliştirmelerini sağlamak ve tüm bölgeleri yeni ortama uyum sağlayabilecek özelliklerle donatmak" için gayret göstermektedirler. (Kara, 2008, s.1)

Bir ülkede gelişme ve kalkınma farklılıkları dikkate alınarak ve geri kalmış bölgeleri kalkındırabilmek amacıyla gelişmişlik seviyelerine göre bölgeler oluşturulmaktadır. Bölgeler arası ekonomik dengesizliklerin azaltılması ve özel sektör yatırımlarının bölgeler arası dengeli gelişmeyi sağlayacak şekilde kalkınmada öncelikli yörelere yönlendirilmesi için bazı vergi indirimi ve muafiyetleri gibi doğrudan teşvikler de verilmektedir.

Ülkelerin, bölgelerin ve şehirlerin yatırım çekme potansiyellerinin arttırılmasının ön koşulu olarak başta ulaştırma, çevre ve enerji olmak üzere gerekli altyapının asgari düzeyde oluşturulması gerekir. Yatırım için arsa, altyapı ve donatıların mevcudiyeti, iş gücü piyasasının özellikleri, nitelikli eleman, eğitim ve araştırma kurumlarının mevcudiyeti gibi faktörler işletmelerin faaliyetlerini, yatırım tercihlerini, üretim maliyetlerini ve yörenin çekiciliğini etkilemesi beklenmektedir.

“Bölgesel Kalkınmada Üniversite-Sanayi işbirliği etkili ve yararlı bir yöntem olarak görülmektedir. Bölgesel kalkınma çerçevesinde bölgedeki kalkınmayı tetikleyici bir faktör olarak üniversiteler, araştırma geliştirme, yenilikçilik, teknolojik bilgi üretimi ve transferi yoluyla sanayinin ihtiyaç duyduğu teknolojiyi sağlayabilmekte" bölgedeki diğer aktörleri harekete geçirebilmektedir. (Telli Üçler, 2014, s. 112) 
Üniversiteler eğitim, öğretim ve araştırma faaliyetleri, sosyal kültürel etkinlikleri ile içinde bulunduğu bölgenin gelişmesi ve kalkınmasına katkıda bulunurlar. Üniversiteler bölgesel ekonomik kalkınmaya "Bilgi Tabanlı" kalkınma kavramına uygun katkılarda bulunmaktadır. Ekonomik kalkınmayı uyarıcı bir faktör olarak Üniversiteler teknolojik bilgi üretimi yoluyla özel sektörün ihtiyaç duyduğu "Teknoloji” girdisini sağlayabilmektedir. Devlet-Üniversite-Sanayi üçlü organizasyonu bölgesel kalkınmada en etken yöntemlerden birisi olarak görülmektedir. (Sakınç ve Aybarç Bursalığlu, 2011, s. 2163)

Üniversite sanayi işbirliği, üniversitelerin ve sanayi kuruluşlarının mevcut imkânlarını birleştirerek bilimsel, teknolojik ve ekonomik yönden gelişmeleri için ortak çalışmalar yapmaları ve kaynakları verimli olarak kullanabilmeleridir. Üniversiteler mezunlarına uygulanabilir bilgiler veren, girişimcilik kültürü aşılayan ve araştırmayı teşvik eden kurumlardır.

Üniversitelerin temel görevi "araştırma ve eğitim olup, üniversiteler bilgiyi yaratır, muhafaza eder, paylaşır ve toplum menfaati için kullanır. Sanayi ise bilgiyi uygulamalı biçimde kullanıp ürüne dönüştürür. Her şeyin çok hızlı değiştiği ve yenilendiği bilgi toplumunda" üniversite-sanayi ilişkileri de değişmektedir. (Erdil, Pamukçu ve Akçanak, 2013, s. 95)

ABD'de 1951 y1lında Silikon Vadisi ile temeli atılan üniversite sanayi işbirliği, 1980'li yıllarda Japonya, İngiltere, Fransa, Almanya, Güney Kore gibi gelişmiş ülkelerde teknoloji geliştirme bölgeleri olarak kurumsallaşmaya başlamıştır. Bu kurumların isimleri ülkelere göre değişse de amaç olarak üniversite sanayi işbirliğine dayanmaktadır. ( Tunalı ve Toprak, 2017, s.238)

Kamu üniversite sanayi işbirliği (KÜSİ)'nin üniversite açısından kazanımları şöyle siralanabilir:

- $\quad$ Üniversite sanayi işbirliği ve araştırma geliştirme çalışmaları ile sanayinin problemlerine çözüm geliştirme firsatı bulunur. İşbirlikleri sayesinde özel sektör ve kamu fonlarından faydalanma imkânı oluşur.

- Bölgenin ekonomik, sosyal ve kültürel bakımdan gelişmesine ve kalkınmasına katkıda bulunulur.

- Üniversite öğrencileri sanayi işletmelerinde staj yaparak endüstriyel tecrübe kazanma imkânı elde eder. Üniversitenin mezunlarına iş ve istihdam firsatı oluşur.

- Akademisyenler ortak araştırma sonuçlarının yayın haklarını elde eder. Üniversite faaliyetlerine ve öğretim elemanlarına eğitim ve araştırma çalışmaları için mali destek sağlama fursatı doğar. Öğretim elemanları araştırmalarında 
sanayicilerin fabrikalarını ve imalathanelerini laboratuvar olarak kullanabilme imkânı elde eder.

Kamu üniversite sanayi işbirliğinden sanayi açısından şu kazanımlar elde edilebilir:

- Sanayiciler üniversitelerin laboratuvar imkânlarına ve yetişmiş insan kaynakları gibi araştırma alt yapısına erişebilir. Yeni teknolojilerin geliştirilmesi ve eskiyen teknolojilerin yenilenmesi firsatlarından faydalanır, rekabet güçleri ve ar-ge kapasiteleri artabilir.

-Sanayiciler üniversitelerin sürekli eğitim merkezlerinden yararlanabilir. Üniversite sanayi işbirliği ile araştırma geliştirme imkânları artabilir, sonuçlar sanayicilerle ve toplumla paylaşılabilir.

- $\quad$ Araştırmalar ve danışmanlık hizmetleri ile sanayicilerin sorunlarına çözüm yolları bulunabilir. Akademik personelin teorik bilgileri ve sanayicilerin tecrübeleri ve uygulama kabiliyetleri ile teknolojisi yüksek ürünler üretilebilir.

- $\quad$ Sanayiciler işletmelerinde istihdam edeceği insan kaynaklarını staj veya endüstriye dayalı öğrenme yolu ile seçebilir.

Kamu üniversite sanayi işbirliğinin kamu açısından kazanımları şunlardır:

- Devletin üniversite sanayi işbirliğinden beklentileri; teknoloji tabanlı ekonomik gelişme, bölgeler arası gelişmişlik farklarının azaltılması, sürdürülebilirliğin sağlanması, temel araştırmaların desteklenmesi ve kamusal yarar olarak sıralanabilir.

- KÜSİ ile kamu; araştırma geliştirme çalışmalarını, yenilikçiliği ve inovasyonu teşvik etmekte, rekabetçiliği güçlendirerek ekonomik büyümeyi hızlandırmayı hedeflemektedir.

Üniversitelerin belirlediği stratejik ifadelerde bölgesel kalkınmaya daha çok vurgu yapılmaktadır. Yenilikçilik konusuna üniversitelerin yarısını bulmayan kısmının değindiği dolayısıyla Türkiye'de akademik girişimcilik olgusunun başlangıç durumunda olduğu söylenebilmektedir. Üniversitelerin büyük çoğunluğunda sürekli eğitim merkezlerinin kurulduğu, teknokentler ve teknoloji transfer merkezlerinin ise daha ziyade gelişmiş bölgelerde bulunduğu tespit edilmiştir. (Y1ldırım, 2014, s. 157)

Üniversitenin kent ekonomisine katkısı konulu bir araştırmada, bir üniversite öğrencisinin aylık ortalama 602 TL.lik harcama yaptığı ve özellikle şehir dışından gelen öğrencilerin daha fazla harcama yaparak bölgenin ekonomisine önemli katkılar sağladığı tespit edilmiştir. (Dağlar ve Durukan, 2011, s. 57) 
Türkiye'de 2007 yılı itibariyle bütün illerde üniversite kurulmuştur. Bu araştırmayla, TR82 Bölgesindeki Çankırı, Kastamonu ve Sinop illerindeki üniversitelerin, illerin kalkınma durumlarına katkılarını ortaya koymak ve kamu üniversite sanayi işbirliği ile ilgili faaliyetleri incelemek amaçlanmıştır. $\mathrm{Bu}$ çalışmayla TR82 bölgesindeki faaliyetlerin yanında, Türkiye'deki kamu üniversite sanayi işbirliği mekanizmalarının da ortaya konulmasının literatüre katkı sağlayacağ düşünülmektedir.

\subsection{Türkiye’de Kamu Üniversite Sanayi İşbirliği (KÜSİ) Uygulamaları}

Türkiye'de Kamu Üniversite Sanayi işbirliği mekanizmalarının başında Teknoloji Geliştirme Bölgeleri gelmektedir. 4691 sayılı Teknoloji Geliştirme Bölgeleri Kanunu, 06.07.2001 tarihinde yürürlüğe girmiştir. Bu Kanun ile düzenlenen ve Teknopark (Teknokent) olarak da adlandırılan bu yapıyla, üniversitelerdeki araştırma geliştirme sonuçlarının sanayiye aktarılması, ileri teknolojiyle mal üretmek isteyen girişimcilerin faaliyetlerini üniversitenin yakınında yürütebilmeleri ve imkânlarından yararlanılması arzu edilmektedir. Türkiye'de 63 Teknopark kurulmuş olup bunların yaklaşık ellisi faal durumdadır.

Teknoloji Geliştirme Bölgeleri içerisinde akademisyenler ile işletmeler arasında işbirlikleri kurulabilmesi, akademi ile iş dünyası arasında ortak projelerin gerçekleştirilmesi, araştırma sonuçlarının ticarileştirilmesi, danışmanlık sağlanması amacıyla Teknoloji Transfer Ofisleri yer almaktadır. Teknoloji Transfer Ofisleri, Teknoloji Geliştirme Bölgelerinin dışında üniversite birimi olarak da çalışabilmektedir.

2014-2018 yılları arasını kapsayan 10. Kalkınma Planında, "üniversite ve kamu kurumları bünyesindeki araştırma merkezlerinin, özel sektörle yakın işbirliği içinde çalışan, nitelikli insan gücüne sahip, tüm araştırmacılara kesintisiz hizmet veren ve etkin bir şekilde yönetilen sürdürülebilir yapılara dönüştürüleceği" belirtilmektedir. "Nitelikli insan gücü için üniversite, sanayi kamu ve araştırma merkezleri arasındaki işbirliğini geliştirip uygun ortam ve koşullar sağlanarak ülkemizin cazibe merkezi haline getirilmesi amaçlanmaktadır. Teknoloji geliştirme bölgelerinin yapısı ve işleyişi; üniversite sanayi işbirliğini, işletmeler arası ortak Ar-Ge ve yenilik faaliyetlerini ve yenilikçi girişimciliği en üst düzeye çıkarmak üzere etkinleştirileceği” vurgulanmaktadır.

Türkiye'de, Küçük ve Orta Ölçekli İşletmeleri Geliştirme ve Destekleme İdaresi Başkanlığı, Türkiye Bilimsel ve Teknolojik Araştırma Kurumu, T.C. Bilim Sanayi ve Teknoloji Bakanlığı bünyesindeki çeşitli destek mekanizmaları vasitasıyla devlet, kamu üniversite ve sanayi işbirliğini teşvik edici çalışmalar yapmaktadır.

KÜSİ kapsamında KOSGEB tarafından, Ar-Ge ve inovasyon projeleri olan küçük ve orta büyüklükteki işletmeleri (KOBİ) desteklemek amacıyla Teknoloji Merkezleri (TEKMER) kurulabilmektedir. TEKMER, KOSGEB'in 
koordinasyonu altında üniversitelerle, küçük ve orta büyüklükteki işletmelerin bir araya gelip Ar-Ge çalışmalarında işbirliği yaptıkları yerlerdir. TEKMER'in kuruluş amaçları; yeni teknolojiye ve inovasyona yönelik girişimciliğin teşvik edilmesi, üniversitelerdeki teknolojik ve bilimsel birikimden KOBİ'lerin yararlanmasını sağlamak, Ar-Ge ve inovasyon çalışma sonuçlarının ticarileştirilmesine ve yatırıma yönlendirilmesine aracılık etmektir.

TEKMER'e proje ile başvuran işletmelere, başlangıç sermayesi, danışmanlık, kira, makine teçhizat, personel gideri gibi konularda destekler verilebilmektedir.

Kamu üniversite ve sanayi arasında diğer işbirliği yapabilme mekanizmalarıysa; TÜBİTAK'ın Üniversite Sanayi Ortak Araştırma Merkezleri Programı, Türk Teknoloji Geliştirme Vakfi, Üniversite Sanayi İşbirliği Teknoloji Uygulama Araştırma Merkezi ve sürekli eğitim merkezleridir.

TÜBİTAK'ın Teknoloji ve Yenilik Destek Programları (TEYDEP), hibe destekli programları, T.C. Bilim Sanayi ve Teknoloji Bakanlığı'nın sanayi tezlerini destekleme programı (SANTEZ), döner sermaye üzerinden sözleşme temelli projeler, bilimsel araştırma projeleri merkezi (BAP), merkezi araştırma laboratuvarı ve araştırma uygulama merkezleri de diğer işbirliği araçlarıdır.

Üniversite sanayi işbirliğine, T.C. Bilim Sanayi ve Teknoloji Bakanlığı kamuyu da dâhil ederek kamu, üniversite, sanayi işbirliğini sağlamak amacıyla çalışmalar başlatmıştır. T.C. Bilim Sanayi ve Teknoloji Bakanlığı girişimcilik ve yenilikçilik endeksini 2011 yılından itibaren yayınlamaya başlamıştır.

T.C. Bilim Sanayi ve Teknoloji Bakanlığı tarafından, kamu, üniversite, sanayi, girişimciler, yatırımcılar arasında işbirliği ve etkileşimin sağlanması, paydaşların tek bir nokta üzerinden Ar-Ge fonlarına, araştırmacılara, yatırımcılara ve bilgi kaynaklarına kolay ve hızlı erişiminin sağlanması amacıyla, Kamu Üniversite Sanayi İşbirliği Portalı (KÜSİP) oluşturulmuştur. KÜSİP'in paydaşları olarak; üniversiteler ve teknoloji transfer ofisleri, kamu araştırma merkezleri, sanayi ve ticaret odaları, organize sanayi bölgeleri, özel sektör Ar-Ge ve tasarım merkezleri, teknoloji geliştirme bölgeleri, araştırma/test laboratuvarları, fon sağlayan kurumlar, akademisyenler ve araştırmacılar belirlenmiştir. (https://kusip.gov.tr/kusip/views/hakkinda.htm, Erişim Tarihi 03.07.2018)

TR82 Bölgesi illerinden Çankırı'da 2013 yılında üniversite-sanayi işbirliği çalıştayı yapılarak tarafların işbirliği imkânlarını görüşmeleri, sürdürülebilir ve dinamik bir işbirliğinin geliştirilmesi amaçlanmıştır. Çankırı Karatekin Üniversitesi bünyesinde 03.07.2015 tarihinde “ Kamu Üniversite Sanayi İşbirliği Uygulama ve Araştırma Merkezi” kurulmuştur.

Üniversite sanayi işbirliğini sağlamada kurumsal yapıların başında teknoloji geliştirme bölgeleri gelmektedir. Çankırı Teknoloji Geliştirme Bölgesi kurulması, 
4/6/2018 tarihinde Bakanlar Kurulu'nca kararlaştırılmış ve 25 Haziran 2018 tarihli ve 30459 sayılı Resmi Gazete'nin mükerrer sayısında yayınlanarak resmen kurulmuştur. Üniversite sanayi işbirliğine önemli katkısı olacağı düşünülen ve Çankırı Yakınkent Organize Sanayi Bölgesi'ne inşa edilecek bu bölgede; biyoteknoloji, nanoteknoloji, savunma, kimya, yazılım, bilişim, elektronik ve haberleşme teknolojileri alanlarında faaliyet gösteren firmaların ve araştırmacıların yer alması planlanmıştır. (https://karatekin.edu.tr/teknoparkcankiri, Erişim Tarihi 03.07.2018)

\subsection{Sanayicilerin Nitelikli Ara Eleman Talebi ve Meslek Yüksekokulları}

Üniversite sanayi işbirliği kapsamında özellikle sanayicilerin talep ettiği tekniker ve nitelikli meslek elemanı talebini karşılamak amacıyla sanayiciler ve üniversiteler arasında ortak çalışmalar yapılabilmekte ve iş dünyasının bu beklentileri karşılanmaya çalışılmaktadır.

Sanayiciler ve hizmet sektörü, değişen ve gelişen teknolojilere uyum sağlayabilen ve yeni yetenekler kazandırılmış nitelikli ara eleman, meslek ve teknik eleman talebinde bulunmaktadır. Üniversiteler ön lisans düzeyinde meslek yüksekokulları (MYO) açıp nitelikli teknik eleman ve meslek elemanı yetiştirerek sanayicilerin bu talebini karşılamaya çalışmaktadır.

Meslek yüksekokulları müfredat programlarını düzenlerken sanayi ve hizmet sektörünün görüş ve önerilerini almaya çalışmaktadır. 2002 y1lında kapsamlı olarak ele alınan MEB/YÖK meslek yüksekokulları müfredat geliştirme projesinde, sanayicilerin müfredatla ilgili fikirleri alınmaya çalışılmıştır. Teknolojideki hızlı gelişmeler sanayicilerle daha yakın bir işbirliğini ve müfredat programlarının daha kısa sürelerde gözden geçirilmesini ve yenilenmesini zorunlu k1lmaktadir.

Meslek yüksekokullarındaki öğretim elemanlarının hızla gelişen teknolojiye ayak uydurmalarında sanayi ile yakın işbirliği çok önemlidir. Teknolojik öğrenme; yaparak, kullanarak, uyum göstererek ve etkileşerek öğrenme şeklinde gerçekleşir. 1999 yılında Ankara Sanayi Odası ile yapılan bir işbirliği protokolü kapsamında Ankara Üniversitesinin kendisine bağlı meslek yüksekokullarından belirlediği öğretim elemanları, sanayi kuruluşlarında bilgi ve becerilerini geliştirmek amacıyla bir ay süreli gözlem ve incelemelerde bulunmuşlardır.

Meslek Yüksekokulu öğrencileri zorunlu staj yapma dönemlerinde endüstriye dayalı öğrenme yapabilmekte, işyerlerini yakından tanıyabilmekte, mezun olduktan sonra da istihdam edilebilmelerinin yolu açılabilmektedir. Öğretim elemanları öğrencilerin staj yaptıkları işletmeleri ziyaret ederek sanayicilerle yakından görüşme ve gelişmeleri takip edebilme firsatı bulmaktadır. 
Meslek Yüksekokulları İl Danışma Kurulu ve Program Geliştirme Kurulu toplantılarında, işletmelerin ihtiyaç duyduğu nitelikli ara eleman ihtiyacı tespit edilebilmekte ve ona uygun bölüm ve programlar açılmasının adımı atılabilmektedir. $\mathrm{Bu}$ kurullarda meslek yüksekokullarının bulunduğu bölgede faaliyette bulunan sanayiciler de bulunmakta ve üniversiteye taleplerini aktarabilmektedir.

\section{Araştırmanın Metodolojisi}

\subsection{Araştırmanın Amacı ve Kapsamı}

$\mathrm{Bu}$ araştırmanın amacı; TR82 bölgesindeki Çankırı, Kastamonu ve Sinop illerinin kalkınma durumlarını, bölgedeki üniversitelerin buna etkilerini ve kamu üniversite sanayi işbirliği çalışmalarını incelemektir. Bu çalışma; TR82 bölgesindeki Çankırı, Kastamonu ve Sinop illerini kapsamaktadır.

\subsection{Yöntem}

Araştırmanın yöntemi; konu ile ilgili ulusal istatistiklerden ve TR82 bölgesindeki bölgesel kalkınma ajansı, ticaret ve sanayi odaları, üniversiteler, bilim sanayi ve teknoloji il müdürlüklerinin kamuya açık kaynaklarından elde edilen verilerden yararlanarak, mevcut durumu tespit etmek ve konuyu analiz etmektir.

\subsection{TR82 Bölgesiyle İlgili Temel Ekonomik Göstergeler}

TR82 Bölgesi, "istatistiki bölge birimleri sınıflandırmasında düzey 2 bölgeleri esas alınarak Çankırı, Kastamonu ve Sinop illerini kapsayacak şekilde belirlenmiştir. Bölgesel kalkınmayı gerçekleştirmek üzere bu bölgede T.C. Kuzey Anadolu Kalkınma Ajansı (KUZKA), 08.02.2006 tarih ve 26074 say1l Resmi Gazetede yayımlanan 5449 sayılı Kalkınma Ajanslarının Kuruluşu Koordinasyonu ve Görevleri Hakkındaki Kanun'a istinaden, 25.07.2009 tarihli ve 27299 sayılı Resmi Gazetede yayımlanan Bakanlar Kurulu kararı ile kurulmuştur." (www.resmigazete.gov.tr, Erişim Tarihi: 05.12.2017) 
Tablo 1: TR82 Bölgesiyle İlgili Seçilmiş Göstergeler

\begin{tabular}{|c|c|c|c|c|}
\hline & \multicolumn{2}{|c|}{ TR82 BÖLGESI } & \multicolumn{2}{|c|}{ TÜRKIYE } \\
\hline $\begin{array}{l}\text { Kişi Başına Gayri Safi Katma Değer, } \\
\text { 2011yılı (ABD Dolar1) }\end{array}$ & \multicolumn{2}{|c|}{6594} & \multicolumn{2}{|c|}{9244} \\
\hline $\begin{array}{l}\text { Tarım Sektörünün Gayri Safi Katma Değerdeki } \\
\text { Payı, } 2011 \text { y1lı } \quad \text { \%) }\end{array}$ & \multicolumn{2}{|c|}{23.1} & \multicolumn{2}{|c|}{9.0} \\
\hline $\begin{array}{l}\text { Sanayi Sektörünün Gayri Safi Katma Değerdeki } \\
\text { Pay1, } 2011 \text { y1l1 }(\%)\end{array}$ & \multicolumn{2}{|c|}{20.1} & \multicolumn{2}{|c|}{27.5} \\
\hline $\begin{array}{l}\text { Hizmetler Sektörünün Gayri Safi Katma } \\
\text { Değerdeki Payı, } 2011 \text { yılı (\%) }\end{array}$ & \multicolumn{2}{|c|}{56,9} & \multicolumn{2}{|c|}{63,5} \\
\hline Toplam Öğretim Elemanı Sayısı, & \multicolumn{2}{|c|}{363} & \multicolumn{2}{|c|}{100504} \\
\hline Toplam Öğretim Elemanı Sayısı, & \multicolumn{2}{|c|}{1811} & \multicolumn{2}{|c|}{156168} \\
\hline $\begin{array}{l}\text { Toplam Öğretim Elemanı Sayısındaki Değişim } \\
(\%)\end{array}$ & \multicolumn{2}{|c|}{399} & \multicolumn{2}{|c|}{55} \\
\hline İstihdam Edilenlerin Sektörel Dağılımı, & 2011 & 2013 & 2011 & 2013 \\
\hline Tarım & 53.6 & 40.6 & 25.5 & 23.6 \\
\hline Sanayi & 13.4 & 18.6 & 26.5 & 26.4 \\
\hline Hizmetler $(\%)$ & 33.0 & 40.08 & 48.0 & 50.0 \\
\hline
\end{tabular}

Kaynak: TÜİK Bölgesel Gayri Safi Katma Değer Tabloları Veri Tabanı (www.tuik.gov.tr Erişim Tarihi: 29.12.2017)

Tablo 1' de görüldüğü gibi, TR82 bölgesinde 2011 yılında kişi başına gayri safi katma değer 6594 dolar olmuştur. Bu değer 9244 dolar olan Türkiye ortalamasının oldukça altında kalmaktadır.

Tablo 1'de, tarım sektörünün gayri safi katma değerdeki payı Türkiye ortalaması 9.0 iken, bu bölgeninki 23.0 olarak görülmektedir. Bölgede tarım ağırlıklı bir ekonomik yap1 gözükmektedir. İstihdam edilenlerin sektörel dağılımına baktığımızda tarımda çalışanların ağırlıkta olduğu ancak 2011 yılından sonraki rakamlarda sanayi ve hizmetler sektörüne önemli kaymalar olduğu tespit edilmiştir. İstihdam edilenlerin sektörel dağılımında tarım sektörünün payında azalma, sanayi sektörünün payında artma görülmektedir.

Bölgedeki her ilde üniversite olup öğrenci ve öğretim elemanı sayılarında ciddi artışlar görülmektedir. Türkiye'de 2008 yılına göre 2015 yılında toplam öğretim elemanı sayısı \%55 artarken, bölgede \%399 artış olmuştur. Bölgedeki illerdeki üniversiteler 2006 ve 2007 yıllarında kurulmalarına rağmen öğretim elemanı sayılarında önemli artışlar olmuştur. 


\subsection{TR82 Bölgesindeki İllerin Kalkınma Durumu}

TR82 bölgesindeki illerin ekonomik yapılarının genellikle tarım ve hizmetler sektörüne dayandığı ve sanayi bakımından fazla gelişmediğini ancak gelişme sürecinde olduğunu söyleyebiliriz. Özellikle Ilgaz dağı tüneli gibi altyapı yatırımları ve diğer sanayi yatırımlarının sanayileşmeyi hızlandırıcı bir etkiye yol açacağı düşünülmektedir.

Kastamonu ili sanayi bakımından fazla gelişmemiştir. İlde orman ürünleri fabrikaları, yem fabrikaları, un fabrikaları, süt ürünleri işletmeleri, mobilya, tekstil ve tuğla fabrikaları vardır. 2007 yılında Kastamonu ve Tosya organize sanayi bölgeleri kurulmuş olup, Taşköprü organize sanayi bölgesi ise kurulum aşamasındadır.

Çankırı ili tarım, hayvancılık imalat sanayi ve madencilik sektörü ağırlıklı bir ekonomik yapıya sahiptir. Çankırı'da Organize Sanayi Bölgelerindeki İşletmelerin yanında Kamu İktisadi Teşekkülü olan MKEK Çankırı Silah Fabrikası silah sanayi ürünleri üretmekte, TCDD İşletmesi olan Çankırı Makas Fabrikası demiryolu makası üretimi yapmaktadır. Tuz, un, makarna, beyaz ve kırmızı et ürünleri, elektrikli küçük ev aletleri, seramik üreten sanayi kuruluşları vardır. Yakın kent organize sanayi bölgesinde Japon girişimcilerle Türk girişimciler ortaklaşa, araba lastiği üretimi yapmak üzere Sumitomo Rubber Oto Lastik Fabrikasını kurmuşlardır. Tam kapasitede yaklaşık 2500 kişinin çalışacağı ifade edilen fabrika 2015 yılında üretime başlamıştır.

Sinop ilinde sanayi sektöründe, toprak sanayi, orman ürünleri, gıda sanayi ile birlikte kimya, metal, plastik, tekstil ve cam sanayisinde faaliyet gösteren sanayi işletmeleri mevcuttur.

Planlı sanayileşmeyi, düzenli kentleşmeyi ve çevrenin korunmasını sağlamak amaciyla kurulan organize sanayi bölgelerinin sayıs1 TR82 bölgesinde artmaktadır. Bu artışın sanayileşmeyi teşvik ederek bölgenin kalkınmasına olumlu katkıda bulunacağı düşünülmektedir (https://osbbs.sanayi.gov.tr). 
Tablo 2: TR82 Bölgesindeki Organize Sanayi Bölgeleri (OSB) İle İlgili İstatistiki Bilgiler

\begin{tabular}{|l|c|c|c|c|}
\hline OSB'nin Adı & $\begin{array}{c}\text { OSB'nin } \\
\text { Faaliyet } \\
\text { Durumu }\end{array}$ & $\begin{array}{c}\text { OSB'nin } \\
\text { Tipi }\end{array}$ & $\begin{array}{c}\text { OSB'nin } \\
\text { Kuruluş } \\
\text { Y1lı }\end{array}$ & $\begin{array}{c}\text { OSB'deki } \\
\text { Parsel } \\
\text { Sayısı }\end{array}$ \\
\hline Çankırı Çerkeş OSB & Faal & Karma & 2005 & 14 \\
\hline Çankırı Orta OSB & Faal & Karma & 2005 & - \\
\hline Çankırı Şabanözü OSB & Faal & Karma & 2012 & 3 \\
\hline Çankırı Yakınkent OSB & Faal & Karma & 1990 & 51 \\
\hline Çankırı Korgun OSB & Kamulaştırma & Karma & 2006 & - \\
\hline Kurşunlu Çavundur OSB & Faal & Karma & 1993 & 35 \\
\hline Kastamonu OSB & Kamulaştırma & Karma & 2014 & - \\
\hline Kastamonu Taşköprü OSB & Faal & Karma & 2009 & 30 \\
\hline Tosya OSB & Faal & Karma & 2013 & 47 \\
\hline Seydiler OSB & Faal & Karma & 1991 & 44 \\
\hline Sinop OSB & Faal & Karma & 1998 & 6 \\
\hline Sinop Boyabat OSB & Karma & 2016 & \\
\hline
\end{tabular}

Kaynak: T.C. Bilim Sanayi ve Teknoloji Bakanlığı OSB Bilgi Sitesi,

(Erişim Tarihi: 10.04.2017)

Tablo 2'de, TR82 Bölgesindeki organize sanayi bölgelerinin tamamının karma tipte olduğu görülmektedir. Bu durum, oraya kurulacak işletmeler için bir sektör kısıtlaması olmadığını ifade etmektedir. Yatırımlarda Devlet yardımları açısından Çankırı ve Sinop beşinci bölgede, Kastamonu dördüncü bölgede bulunmaktadır. Organize sanayi bölgelerinde yapılacak yatırımlar bir alt bölgenin teşviklerinden yararlandığı için Çankırı ve Sinop'taki organize sanayi bölgelerine yatırım yapacak olan yatırımcılar en yüksek teşvikten yararlanabileceklerdir. Çankırı'da Korgun, Şabanözü, Çerkeş illerinde bulunan organize sanayi bölgelerinde doluluk oranı \% 100 'e yaklaşmıştır. 
Tablo 3: TR82 Bölgesindeki İllerle İlgili Temel Göstergeler

\begin{tabular}{|c|c|c|c|c|}
\hline & ÇANKIRI & KASTAMONU & SINOP & TÜRKIYE \\
\hline $\begin{array}{l}\text { Nüfus } \\
\text { (31 Aralık 2016) }\end{array}$ & 183880 & 376945 & 205478 & 79814871 \\
\hline $\begin{array}{l}\text { Yıllık Nüfus Artış Hızı } \\
\text { 2015-2016 (Binde) }\end{array}$ & 16.1 & 11.5 & 6.6 & 13.5 \\
\hline $\begin{array}{l}\text { Net Göç H1z1 } \\
\text { 2015-2016 (Binde) }\end{array}$ & 1.5 & 4.5 & 2.0 & \\
\hline $\begin{array}{l}\text { İthalat } \\
2016 \text { Y111 }(1000 \$)\end{array}$ & 93641 & 151934 & 11119 & 198616139 \\
\hline $\begin{array}{l}\text { İhracat } \\
2016 \text { Y11 }(1000 \$)\end{array}$ & 77385 & 43396 & 21494 & 142545946 \\
\hline $\begin{array}{l}\text { Kişi Başına Toplam Elektrik } \\
\text { Tüketimi } 2014 \text { (Kwh) }\end{array}$ & 1703 & 2110 & 1604 & 2669 \\
\hline $\begin{array}{l}\text { İllere Göre Mutluluk Düzeyi } \\
2013(\%)\end{array}$ & 73.5 & 60 & 77.7 & 59 \\
\hline $\begin{array}{l}\text { İllere Göre Umut Düzeyi } \\
2013(\%)\end{array}$ & 79.8 & 80.2 & 81.1 & 77 \\
\hline $\begin{array}{l}\text { Ev Sahibi Olan Hane Halk1 } \\
2011 \text { y1l1 (\%) }\end{array}$ & 74.9 & 74.8 & 73.7 & 67.3 \\
\hline $\begin{array}{l}\text { Konut Satış Say1sı } \\
(2016 \text { y1l1) }\end{array}$ & 2829 & 5477 & 3443 & 1289320 \\
\hline $\begin{array}{l}\text { Bin Kişi Başına Otomobil } \\
\text { Sayıs1 } \quad(2016 \text { yıl1) }\end{array}$ & 88 & 135 & 121 & 121 \\
\hline $\begin{array}{l}\text { Yatırımlarda Devlet } \\
\text { Yardımları Açısından } \\
\text { Bulunduğu Bölge (2016 yıl1) }\end{array}$ & 5 & 4 & 5 & \\
\hline $\begin{array}{l}\text { İşsizlik Oranı } \\
2016 \text { Yı1lık (\%) }\end{array}$ & TR82 Bölges & şsizlik Ortalamas & (\%) 5.8 & 10.9 \\
\hline
\end{tabular}

Kaynak: TÜİK Temel İstatistikler (www.tuik.gov.tr Erişim Tarihi: 29.12.2017)

Tablo 3' de, TR82 Bölgesindeki İllerin nüfus artış hızlarında pozitif yönlü olumlu gelişmeler görülmektedir. 2012-2013 net göç hızına bakıldığında, her üç il de göç alan iller arasındadır. Tablo 3'de görüldüğü gibi, 2016 yılında Türkiye'de en yüksek istihdam oranı \% 54 ile TR82 (Çankırı, Kastamonu, Sinop) Bölgesi'nde gerçekleşmiş olup, işgücüne katılma oranı en yüksek bölge olmuştur. Ayrıca 2016 yılında Türkiye işsizlik oranı \%10.9 iken, TR82 Bölgesinde işsizlik oranı \%5.8 olmuştur. Bu sonuçla TR82 Bölgesi, Türkiye'de işsizliğin en düşük olduğu bölge olmuştur.

İllere göre mutluluk düzeyi ve mutlu olduğunu beyan edenlerin oranında Kastamonu ili 2013 yılında Türkiye ortalamasının az üzerindedir. Sinop ili \%77.7 oranı ile Türkiye'de kendini mutlu hisseden iller arasında birinci sıradadır. İllere göre umut düzeyi ve gelecekten umutlu olduğunu beyan edenlerin oranında 
Kastamonu ve Çankırı illeri 2013 yılında Türkiye ortalamasının az üzerindedir. Sinop ili \%81.1 oranı ile Türkiye"de kendini gelecekten umutlu hisseden iller arasında en üst sıralardadır.

Sanayileşmede de ölçü olarak alınan kişi başına toplam elektrik tüketimi 2012 yılında her üç ilde de Türkiye ortalaması olan 2 577'nin altındadır. Bu veri her üç il için de sanayileşme açından olumsuz bir durumu göstermekte yani bu illere yeterince sanayi yatırımı yapılmadığını ifade edebilmektedir.

Bölgede ev sahibi olan hane halkı Türkiye ortalamasının üzerindedir. Bin kişi başına otomobil sayısında Çankırı 88 ile Türkiye ortalaması olan 121'in altında, diğer illerden Sinop Türkiye ortalaması ile aynı, Kastamonu ili ortalamanın az üzerindedir.

Tablo 4: TR82 Bölgesindeki Üniversitelerle İlgili İstatistikler

\begin{tabular}{|c|c|c|c|}
\hline$\dot{\mathrm{IL}}$ & ÇANKIRI & KASTAMONU & SINOP \\
\hline Üniversitenin Ad1 & $\begin{array}{c}\text { Çankırı } \\
\text { Karatekin }\end{array}$ & Kastamonu & Sinop \\
\hline Kuruluş Y11ı & 2007 & 2006 & 2007 \\
\hline $\begin{array}{l}\text { Üniversitedeki Toplam Öğrenci } \\
\text { Sayısı (2016 yılı) }\end{array}$ & 14218 & 27265 & 9553 \\
\hline $\begin{array}{l}\text { Üniversitedeki Toplam Akademik } \\
\text { Personel Sayıs1 (2016 y1l1) }\end{array}$ & 621 & 670 & 449 \\
\hline $\begin{array}{l}\text { Üniversitedeki Toplam İdari Personel } \\
\text { Sayıs1 (2016 y1l1) }\end{array}$ & 299 & 415 & 273 \\
\hline Üniversitedeki MYO Sayıs1 (2016 y1lı) & 4 & 13 & 5 \\
\hline $\begin{array}{l}\text { MYO'lardaki Toplam Öğrenci Sayıs1 } \\
(2016 \text { y1l1) }\end{array}$ & 6129 & 11422 & 4682 \\
\hline $\begin{array}{l}\text { MYO'daki Toplam Öğrenci } \\
\text { Sayısının Üniversitedeki Toplam } \\
\text { Öğrenci Sayısına Oranı (\%), } 2016 \text { y1lı }\end{array}$ & 43 & 42 & 49 \\
\hline $\begin{array}{l}\text { Üniversitedeki Toplam Öğgrenci } \\
\text { Sayısının İldeki Toplam Nüfusa } \\
\text { Oranı }(\%), 2016 \text { yılı }\end{array}$ & 7.7 & 7.2 & 4.7 \\
\hline Üniversitenin 2014 Y1lı Bütçesi (TL.) & 74239600 & 79881000 & 59276810 \\
\hline Üniversitenin 2015 Y1lı Bütçesi (TL.) & 93835802 & 104783722 & 74875047 \\
\hline Üniversitenin 2016 Y1lı Bütçesi (TL.) & 92037529 & 118735000 & 96551150 \\
\hline
\end{tabular}

Kaynaklar: İlgili Üniversitelerin İdari Faaliyet Raporları, 1) www.karatekin.edu.tr 2) www.kastamonu.edu.tr 3) www.sinop.edu.tr (Erişim Tarihi: 11.04.2017)

Tablo 4'de görüldüğü gibi bölge illerindeki üniversiteler yaklaşık on yıl önce kurulmuş olmalarına rağmen, öğrenci sayısı, akademik ve idari personel sayısı bakımından hızlı bir gelişme göstermişlerdir. Üniversitelerdeki öğrencilerin 
yaklaşık yarısına yakını meslek yüksekokullarında eğitim görmektedir. Bu da hem bölgedeki hem de Türkiye'deki sanayinin ihtiyaç duyduğu nitelikli iş gücünün yetişmesine katkı sağlamaktadır.

\section{TR82 Bölgesinde KÜSİ'den Önceki ve Sonraki Gelişmeler}

TR82 Bölgesindeki KÜSİ çalışmaları, T.C. Bilim Sanayi ve Teknoloji Bakanlı̆̆ı'nın 2013 yılında KÜSİ Stratejisi ve Eylem Planı hazırlarken 26 Düzey 2 Bölgesinde yaptığı toplantılarla başlamıştır. Bu nedenle 2013 yılı öncesi ve sonrası seçilmiş bazı göstergeler analiz edilecektir.

\subsection{TR82 Bölgesindeki Üniversitelerle İlgili Gelişmeler}

TR82 Bölgesindeki üniversitelerden Kastamonu Üniversitesi 2006, Çankırı Karatekin ve Sinop Üniversitesi 2007 yılında kurulmuş olmalarına rağmen öğrenci ve öğretim elemanı sayıları bakımından önemli artışlar olmuştur.

Tablo 5: TR82 Bölgesindeki Yükseköğretim Kurumlarında Önlisans ve Lisans Düzeyindeki Öğrenci Sayıları ve Yıllık Değişim

\begin{tabular}{|l|l|l|l|l|l|l|l|l|}
\hline & $\mathbf{2 0 0 9}$ & $\mathbf{2 0 1 0}$ & $\mathbf{2 0 1 1}$ & $\mathbf{2 0 1 2}$ & $\mathbf{2 0 1 3}$ & $\mathbf{2 0 1 4}$ & $\mathbf{2 0 1 5}$ & $\mathbf{2 0 1 6}$ \\
\hline Kastamonu Ü. & 7564 & 8611 & 10582 & 13330 & 16450 & 19763 & 22045 & 24960 \\
\hline Çankırı K. Ü. & 4851 & 5606 & 6991 & 8357 & 9105 & 9895 & 11365 & 12707 \\
\hline Sinop Ü. & 2698 & 3294 & 4160 & 4625 & 5018 & 5446 & 7006 & 8878 \\
\hline $\begin{array}{c}\text { Yllık Değişim } \\
(\%)\end{array}$ & & & & & & & & \\
\hline Kastamonu Ü. & - & 13.8 & 22.8 & 26.0 & 23.4 & 20.0 & 11.5 & 13.2 \\
\hline Çankırı K. Ü. & - & 15.6 & 24.7 & 19.5 & 9.0 & 8.7 & 14.9 & 11.8 \\
\hline Sinop Ü. & - & 22.1 & 26.2 & 11.2 & 8.5 & 8.5 & 28.6 & 26.7 \\
\hline
\end{tabular}

Kaynak: https://biruni.tuik.gov.tr/bolgeselistatistik (Erisim Tarihi: 29.12.2017)

Tablo 5'de TR82 Bölgesindeki üniversitelerdeki öğrenci sayılarında 2009 yılından itibaren sürekli artış olduğu görülmektedir. Üniversitelerdeki öğrenci sayılarındaki bu pozitif artışa rağmen, KÜSİ sonrası dönemde Sinop hariç diğer illerde, 2012 yılına göre 2015 yılındaki oransal artış düzeyleri daha düşüktür. Üniversitelerin kurulduğu yıllarda öğrenci sayısındaki oransal artış ise çok yüksektir. 
Tablo 6: TR82 Bölgesindeki Yükseköğretim Kurumlarında Kendi Birimlerinde Görevli Öğretim Elemanı Sayıları ve Yıllık Değişim

\begin{tabular}{|l|c|c|c|c|c|c|c|c|}
\hline & $\mathbf{2 0 0 9}$ & $\mathbf{2 0 1 0}$ & $\mathbf{2 0 1 1}$ & $\mathbf{2 0 1 2}$ & $\mathbf{2 0 1 3}$ & $\mathbf{2 0 1 4}$ & $\mathbf{2 0 1 5}$ & $\mathbf{2 0 1 6}$ \\
\hline Kastamonu Ü. & 252 & 317 & 431 & 519 & 623 & 638 & 705 & 722 \\
\hline Çankırı K. Ü. & 110 & 244 & 332 & 391 & 539 & 603 & 650 & 622 \\
\hline Sinop Ü. & 195 & 221 & 270 & 264 & 380 & 419 & 456 & 464 \\
\hline $\begin{array}{c}\text { Yıllık Değişim } \\
(\%)\end{array}$ & & & & & & & & \\
\hline Kastamonu Ü. & - & 25.7 & 35.9 & 20.4 & 20 & 2.4 & 10.5 & 2.4 \\
\hline Çankırı K. Ü. & - & 121.8 & 36 & 17.7 & 37.8 & 11.8 & 7.7 & -4.3 \\
\hline Sinop Ü. & - & 13.3 & 22.1 & -2.2 & 43.9 & 10.2 & 8.8 & 1.7 \\
\hline
\end{tabular}

Kaynak: https://biruni.tuik.gov.tr/bolgeselistatistik (Erisim Tarihi: 29.12.2017)

Tablo 6'yı incelediğimizde Kastamonu Üniversitesi'nin öğretim elemanı sayısında, ele aldığımız yıllarda sürekli artış olmuştur. Çankırı Karatekin Üniversitesi'nde 2016 yılı, Sinop Üniversitesinde ise 2012 y1lı dışında öğretim elemanı sayısında devamlı artış olmuştur. 2012 yılından 2013 yılına geçildiğinde Çankırı Karatekin ve Sinop Üniversitelerinin öğretim elemanı sayılarında oransal olarak yüksek bir artış vardır.

Öğretim elemanları; yaptıkları bilimsel araştırmalar, ar-ge çalışmaları, projeler ve öğrencilerinin stajlarını kontrol esnasındaki sanayi ile ilişkileriyle KÜSİye olumlu katkıda bulunabilmektedir. Bölgedeki üniversiteler; öğrenci sayısı, akademik ve idari personel ile birlikte bölgenin ekonomisine ve bölge kalkınmasına önemli katkı sağlamaktadırlar. Ayrıca üniversiteler bilimsel faaliyetlerinin yanında, sosyal ve kültürel faaliyetleri ile bölgeye canlılık ve dinamizm getirmektedirler.

Sanayiciler nitelikli eleman ihtiyacının yanında bazı sorunlarının çözümünde üniversiteler ile işbirliğine gidebilmektedir. T.C. Bilim Sanayi ve Teknoloji Bakanlığının koordinasyonunda illerde KÜSİ Planlama ve Geliştirme Kurulları, kamu üniversite sanayi işbirliğinde ortak bir zemin oluşturmaktadır. TR82 Bölgesindeki her üç üniversitede de bulunun Fen Fakültesi ve Mühendislik Fakültelerinin KÜSİ’ye önemli katkılarda bulunacağı beklenmektedir.

\subsection{TR82 Bölgesindeki Nüfus ve Net Göç İle İlgili Gelişmeler}

TR82 Bölgesinde 2013 y1lı öncesinde ve sonrasında toplam nüfus ve nüfus artış hızındaki değişimler incelenmiş, KÜSİ'nin bu artış veya azalışlara olumlu veya olumsuz etkisi açısından anlamlı bir ilişki görülememiştir. 2013 yılı öncesi ile 
sonrası arasındaki net göç hızındaki değişimde de KÜSİ açısından anlamlı bir farklılık tespit edilememiştir.

\subsection{TR82 Bölgesindeki İşsizlik Oranlarıyla İlgili Gelişmeler}

2009 yılından itibaren Türkiye'deki İşsizlik oranlarındaki değişmeler ile TR82 Bölgesi'ndeki değişmeler karşılaştırılmıştır.

Tablo 7: TR82 Bölgesiyle Türkiye İşsizlik Oranlarının Karşılaştırılması (\%)

\begin{tabular}{|l|c|c|c|c|c|c|c|c|}
\hline & $\mathbf{2 0 0 9}$ & $\mathbf{2 0 1 0}$ & $\mathbf{2 0 1 1}$ & $\mathbf{2 0 1 2}$ & $\mathbf{2 0 1 3}$ & $\mathbf{2 0 1 4}$ & $\mathbf{2 0 1 5}$ & $\mathbf{2 0 1 6}$ \\
\hline TÜRKIYE & 14 & 11.9 & 9.8 & 9.2 & 9.7 & 9.9 & 10.3 & 10.9 \\
\hline TR82 BÖLGESİ & 9.4 & 8.3 & 5.7 & 5.6 & 6.4 & 6.5 & 6.8 & 5.8 \\
\hline $\begin{array}{l}\text { Türkiye- TR82 Bölgesi } \\
\text { Arasındaki Fark }\end{array}$ & 4.6 & 3.6 & 4.1 & 3.6 & 3.3 & 3.4 & 3.5 & 5.1 \\
\hline
\end{tabular}

Kaynak: TÜİK Bölgesel İstatistikler (www.tuik.gov.tr Erişim Tarihi: 29.12.2017)

Tablo 7'ye baktığımızda TR82 Bölgesindeki 2009-2016 yılları arasındaki işsizlik oranlarının, Türkiye işsizlik oranlarının altında olduğu görülmektedir. 2013 yılı sonrası Türkiye İşsizlik oranları ile TR82 Bölgesindeki işsizlik oranları arasındaki fark incelendiğinde, 2013 yılı sonrası farkın hiç azalmadığı bilakis devamlı arttığ1 da söylenebilir. Özellikle 2016 yılında bu fark bölge lehine en üst düzeye çıkmıştır. Bu da bölgedeki istihdam açısından önemli bir gelişmedir.

\subsection{Sanayinin Gayrisafi Yurtiçi Hasıla İçindeki Payı ile İlgili Gelişmeler}

Türkiye'deki sanayinin gayrisafi yurtiçi hasıla içindeki payının 2010 yılından itibaren değişimi incelenmiştir.

Tablo 8: Türkiye’de Sanayinin Gayrisafi Yurtiçi Hasıla İçindeki Payı

\begin{tabular}{|l|c|c|c|c|c|}
\hline & $\mathbf{2 0 1 0}$ & $\mathbf{2 0 1 1}$ & $\mathbf{2 0 1 2}$ & $\mathbf{2 0 1 3}$ & $\mathbf{2 0 1 4}$ \\
\hline $\begin{array}{l}\text { Türkiye } \\
\text { Toplamı } \\
\text { (Bin TL) }\end{array}$ & 285383871 & 375613697 & 420266164 & 501220607 & 576440635 \\
\hline Türkiye (\%) & 25 & 27 & 27 & 28 & 28 \\
\hline
\end{tabular}

Kaynak: TÜİK Bölgesel İstatistikler (www.tuik.gov.tr Erişim Tarihi: 29.12.2017)

Tablo 8'de Türkiye'de sanayinin gayrisafi yurtiçi hasıla içindeki payında, 2010 yılından itibaren az da olsa bir artış görülmektedir. Ancak 2014 yılında bir önceki yıla oranla yüzde olarak bir değişiklik görülmemektedir. 
Tablo 9: TR82 Bölgesinin ve Bölgedeki İllerin Gayrisafi Yurtiçi Hasılası İçinde Sanayinin Payı

\begin{tabular}{|l|c|c|c|c|c|c|}
\hline & $\mathbf{2 0 0 9}$ & $\mathbf{2 0 1 0}$ & $\mathbf{2 0 1 1}$ & $\mathbf{2 0 1 2}$ & $\mathbf{2 0 1 3}$ & $\mathbf{2 0 1 4}$ \\
\hline $\begin{array}{l}\text { TR82 Bölgesi } \\
\text { Toplamı } \\
\text { (Bin TL) }\end{array}$ & 1179940 & 1450803 & 1859151 & 2140361 & 2471677 & 2909005 \\
\hline $\begin{array}{l}\text { TR82 Bölgesi } \\
(\%)\end{array}$ & 16 & 17 & 18 & 19 & 19 & 20 \\
\hline $\begin{array}{l}\text { Kastamonu } \\
\text { (Bin TL) }\end{array}$ & 573355 & 718978 & 953284 & 1103531 & 1256581 & 1485234 \\
\hline Kastamonu (\%) & 15 & 16 & 18 & 19 & 20 & 20 \\
\hline Çankırı(Bin TL) & 336807 & 399327 & 544307 & 622478 & 708908 & 853868 \\
\hline Çankırı (\%) & 18 & 19 & 22 & 23 & 22 & 24 \\
\hline Sinop (Bin TL) & 269778 & 332498 & 361560 & 414352 & 506186 & 569901 \\
\hline Sinop (\%) & 15 & 15 & 14 & 14 & 15 & 16 \\
\hline
\end{tabular}

Kaynak: TÜIK Bölgesel İstatistikler (www.tuik.gov.tr Erişim Tarihi: 29.12.2017)

Tablo 9'da TR82 Bölgesindeki ve bu bölgedeki illerin sanayileşme durumunu ve bu konudaki gelişmeleri incelemek için, sanayinin bölgenin gayrisafi yurtiçi hasıla içindeki payının yıllar içindeki değişimine bakılmıştır. TR82 Bölgesinde sanayinin, bölgenin gayrisafi yurtiçi hasılasındaki payında, yüzde olarak az olsa da yıllar itibariyle bir artış görülmektedir. Ancak TR82 Bölgesi ve bu bölgedeki illerin sanayinin gayri safi yurtiçi hasıladaki payı Türkiye'nin yüzde payının altındadır.

TR82 Bölgesindeki illerin gayrisafi yurtiçi hasılalarında sanayinin payı, incelenen yıllar itibariyle Türk Lirası olarak her yıl artmıştır. Yüzde olarak sanayinin gayrisafi yurtiçi hasıladaki payı, Kastamonu'da 2014 yılı hariç her yıl az da olsa artmıştır. Çankırı'da da 2013 yılı hariç olmak üzere yüzde oranı artmıştır. Sinop'ta 2011 ve 2012 yıllarında bu oran, yüzde bir düşmesine rağmen 2014 yılında az da olsa artmıştır. 2013 yılından sonra bölgenin gayrisafi yurtiçi hasılasında sanayinin payında bir azalma olmamış, Kastamonu'da aynı kalıp, Çankırı ve Sinop'ta artmıştır.

\section{Sonuç ve Öneriler}

\subsection{Sonuç}

Bu çalışma; TR82 bölgesindeki Çankırı, Kastamonu ve Sinop illerinin kalkınma durumlarını, bölgedeki üniversitelerin buna etkilerini ve kamu üniversite sanayi işbirliğinin önemine dikkat çekmek amacıyla yapılmıştır. TR82 bölgesindeki 
Çankırı, Kastamonu ve Sinop illerindeki üniversiteler ile sanayi kuruluşlarının bölgesel kalkınma ile ilişkileri üzerinde durulmuştur.

Konu ile ilgili veriler, bu bölgedeki illerin, ticaret ve sanayi odalarının, T.C. Bilim Sanayi ve Teknoloji İl Müdürlüklerinin kamuya açık kaynaklarından ve Türkiye İstatistik Kurumu'nun veri tabanlarından elde edilmiştir. Ayrıca 13-14 Haziran 2013 tarihlerinde Çankırı'da yapılan 'Çankırı'da Üniversite-Sanayi İşbirliği Çalıştayı"na, 15 Şubat 2015 tarihinde Kastamonu'da Kalkınma Ajansı ve üniversite yetkilileri ile yapılan KÜSİ toplantısına ve 30 Ekim 2014 tarihinde Bilim Sanayi ve Teknoloji Bakanlığı Müsteşarının ve üniversitelerin KÜSİ temsilcilerinin katıldığ toplantılara bizzat katılarak konu hakkında birincil kaynaklardan bilgiler edinilmiştir.

KÜSİ kapsamında kamuyu temsil eden T.C. Bilim Sanayi ve Teknoloji İl Müdürlükleri ile üniversiteler ve sanayicilerden elde edilen bilgiler 1şığında konu incelenmiş ve değerlendirilmiştir.

TR82 Bölgesindeki KÜSİ çalışmalarının başlangıcı, T.C. Bilim Sanayi ve Teknoloji Bakanlı̆̆ı'nın KÜSİ Stratejisi Eylem Planı hazırlarken 26 Düzey 2 Bölgesinde yaptığı toplantıların başlangıç yılı olan 2013 yılı alınmıştır. 2013 yılı öncesi ve sonrası bölgedeki nüfus, göç, işsizlik ve gayri safi yurtiçi hasıla rakamlarındaki değişmeler incelenmiştir.

TR82 bölgesinde tarım ağırlıklı bir ekonomik yapı gözükmektedir. Tablo 1'de de görüldüğü gibi tarım sektörünün gayri safi katma değerdeki payı, Türkiye ortalaması yüzde 9,0 iken, bu bölgeninki yüzde 23,0'dür. Ancak Bölgedeki sanayileşme çabaları dikkat çekmektedir.

Türkiye İşsizlik oranları ile TR82 Bölgesindeki işsizlik oranları arasındaki fark, 2013 yılı sonrasında bölge lehine artmış yani bölgedeki işsizlik azalmıştır.

TR82 bölgesindeki illerde üniversitelerin kuruluş tarihleri yeni sayılabilir. Her üç ilde de daha önce başka üniversitelere bağlı üniversite birimleri olmakla birlikte, üniversite kuruluş tarihleri Kastamonu'da 2006, Çankırı ve Sinop'da 2007 yıllarıdır. $\mathrm{Bu}$ illerde üniversitelerin kurulmasıyla birlikte, akademik birimlerin, akademik ve idari personelin ve öğrencilerin sayılarının hızla arttı̆̆ gözlenmiştir. Türkiye'de 2008 yılına göre 2015 yılında toplam öğretim elemanı sayıs1 \%55 artarken, bölgede \%399 artış olmuştur.

Üniversite sanayi işbirliğinde kullanılacak mekanizmaların; teknoloji transfer ofisi, sürekli eğitim merkezleri, KÜSİ araştırma uygulama merkezleri, döner sermaye üzerinden çalışmalar, Kalkınma Ajansları ile işbirliği, endüstriye dayalı öğrenme (staj), sanayiye yönelik TÜBİTAK ve KOSGEB projeleri gibi çalışmalar olduğu tespit edilmiştir. 
Kuzey Anadolu Kalkınma Ajansı'nın olduğu TR82 Bölgesinde üniversite sanayi işbirliğine dönük gayretler vardır. Bu illerdeki üniversitelerin öğrenci sayıları, akademik ve idari personelleri ile bölgesel kalkınmaya büyük katkı sağladığı görülmektedir.

Sanayicilerin talep ettiği nitelikli insan gücünün yetiştirilmesi açısından TR82 bölgesindeki üniversitelerde çok sayıda meslek yüksekokulunun olması, sanayi açısından nitelikli eleman temininde bir avantaj olarak görülebilir. Tablo 4 de Meslek yüksekokullarındaki toplam öğrenci sayısının üniversitedeki toplam öğrenci sayısına oranı 2016 yılı itibariyle Çankırı'da (\%) 43, Kastamonu'da (\%) 42, Sinop'ta (\%) 49 olarak görülmektedir.

\section{2. Öneriler}

1 Temmuz 2017 tarihli ve 30111 say1lı Resmi Gazete'de yayımlanan 7033 No.lu "Sanayinin Geliştirilmesi ve Üretimin Desteklenmesi Amacıyla Bazı Kanun ve Kanun Hükmünde Kararnamelerde Değişiklik Yapılmasına Dair Kanun" KÜSİ'ye dair önemli değişiklikler ve gelişmeler içermektedir. Bu Kanunun 18. maddesi ile 2547 sayılı Kanuna eklenen Ek Madde 32'de "Yükseköğretim kurumları, Ar-Ge ve yenilikçilikle ilgili olarak kamu ve özel sektör ile işbirliği yapmak, üretilen bilgi ve yapılan buluşları fikri mülkiyet kapsamında koruma altına almak ve uygulamaya aktarmak üzere, Yükseköğretim Kurulundan önceden izin almak kaydıyla, yükseköğretim kurumu yönetim kurulunun kararıyla sermaye şirketi statüsünde teknoloji transfer ofisi kurabilirler." ifadesi yer almaktadır. Bu şekilde kurulabilecek teknoloji transfer ofisi KÜSİ’ye büyük katkı sağlayabilecektir.

7033 No.lu Kanun, "yükseköğretim alanındaki istihdam odaklı politikaların oluşturulması ve geliştirilmesi, yeni açılacak eğitim programları ve kontenjanları hakkında görüş ve öneride bulunmak üzere Yükseköğretim Eğitim Programları Danışma Kurulu kurulması hükmünü içermektedir. Ayrıca meslek yüksekokulları ve programlarının açılma standartlarının belirlenmesi, mevcut programların geliştirilmesi mezunların istihdamı ve lisans tamamlama ile ilgili görüş ve önerilerde bulunmak üzere Meslek Yüksekokulları Koordinasyon Kurulu kurulması hükmünü de içermektedir."

Üniversite sanayi işbirliğinin kurumsal ve sürdürülebilir olması, sanayicilerin doğrudan muhatap bulması ve çalışmaların kayıt altına alınması için üniversite içerisinde sanayi ile irtibat sağlayabilecek Kamu Üniversite Sanayi İşbirliği Uygulama ve Araştırma Merkezinin oluşturulması ve etkin çalıştırılması gerekmektedir. Teknopark ve TEKMER ile bu işbirliği daha çok gelişebilir.

Üniversitelerde döner sermaye üzerinden sanayi ile yapılan işlerde vergiler ve bazı kesintiler dolayısıyla işi yapanların aldıkları pay çok düşmektedir. Bu durum işi yapanlar açından motivasyon kaybına sebep olmakta, sanayiciler açısından da işin maliyetini yükseltebilmekte ve sanayiciler üniversitenin dişında başka çareler 
arayabilmektedir. Üniversite ile sanayi arasında ortak projeleri yürütebilmek için Üniversitelerdeki Döner Sermaye Sistemindeki yasal ve mali sıkıntılar giderilmelidir.

Üniversite öğretim elemanlarının yayınlanabilecek çalışmalara öncelik vermesi, buna karşıllı sanayinin bilgi gizliliği sebebiyle işbirliğine mesafeli davranması üniversite sanayi işbirliğinde önemli engel olabilmektedir. Üniversite öğretim elemanları ve sanayiciler ortak Avrupa Birliği (AB) projeleri hazırlayabilir ve Bölge Kalkınma Ajansı kanalıyla da ortak projeler geliştirebilir. Eğitim (müfredat) programının içeriği ile sanayicilerin beklentileri uyumlaştırılabilir. Lisansüstü tezlerin sanayi sektörüne yönelik ve işbirliği içinde hazırlanması teşvik edilebilir.

Üniversitedeki sürekli eğitim, hayat boyu eğitim, yaşam boyu öğrenme adları altındaki merkezler veya döner sermaye işletmeleri aracılı̆̆ ile sanayicinin ihtiyaç duyacağı alanlarda kurslar açılıp eğitimler verilebilir. Üniversiteler uzaktan eğitim yoluyla sanayide çalışanların niteliklerini arttırıcı çalışmalar yapabilir. Sanayide çalışanların kendi alanlarında yüksek lisans çalışmaları teşvik edilebilir. Sanayinin ilgili alanlarında yüksek lisans ve doktora tez konularının belirlenmesinde sanayicilerle işbirliği yapılması faydalı olur.

Bir ülkenin ekonomisinin gelişmesi yüksek kalitede iş gücüne sahip olmasına bağlıdır. Bilgi teknolojilerine bağlı olarak iletişimin gelişmesi ve küreselleşmenin ortaya çıkışı mesleki ve teknik eğitimi de etkilemektedir. Bölgedeki girişimcilerin desteklenmesi, altyapının ve mesleki eğitim kurumlarının güçlendirilmesi bölge kalkınmasına önemli katkı sağlayacaktır.

Türkiye, ulusal rekabet düzeyini yükseltmek uluslararası pazarlarda söz sahibi olmak, Avrupa Birliği ile bütünleşmek için bilgi çağının gerektirdiği insan gücünü yetiştirmek durumundadır. Ülkemizde bunları sağlamak için yapılacak önemli işlerden birisi de iş dünyası ile üniversiteler arasındaki işbirliğinin geliştirilmesidir. Üniversitelerdeki bina, tesis, araştırma ve uygulama birimi, atölye ve laboratuvarlardan ve sürekli eğitim merkezlerinden sanayicilerin yeterli düzeyde faydalanmasına yönelik tedbirler alınmalıdır.

Mesleki ve teknik eğitimin planlanması, uygulanması ve geliştirilmesinde mesleki eğitim kurumları ile endüstri arasında iyi bir işbirliği mekanizmasının kurulması gerekir. KÜSİ sonucunda; Ar-Ge'de işbirliği artabilir, sanayiciler üniversitelerin araştırma geliştirme imkânlarından yararlanabilir ve istihdam edeceği insan kaynaklarını seçebilir.

Meslek yüksekokulları teknolojideki hızlı gelişmelere ayak uydurabilmek için sanayicilerle daha yakın işbirliğine giderek müfredatlarını en az iki yılda bir gözden geçirmeli ve revize etmelidir. Üniversiteler eğitim programlarını 
hazırlarken sanayiciler, hizmet sektörü ve Mesleki Yeterlilikler Kurumu ile daha yakın işbirliğine gitmelidir.

Öğretim elemanlarının yetiştirilmesi ve geliştirilmesi sürekli eğitim merkezleri ile desteklenmelidir. Meslek yüksekokullarının sanayi ve hizmet sektörü ile daha yakın işbirliğinde bulunması ve teorik yapıdan uygulama ağırlıklı derslere geçmesi eğitimde kaliteyi artıracaktır.

Nitelikli iş gücü ihtiyaç planlaması ve istihdam ihtiyaçları doğrultusunda meslek odaları ve IŞSKUR gibi konu ile ilgili kurum ve kuruluşların görüşleri alınarak, hangi meslek alanında eleman açı̆̆ı varsa ona yönelik MYO bölüm ve programların açılması ülke ve bölge kalkınması için daha faydalı olacaktır. İl İstihdam Kurulu, Meslek Yüksekokulu İl Danışma Kurulu ve Program Geliştirme Kurulları daha etkin hale getirilerek sanayicilerin talepleri ve önerileri uygulamaya konabilecektir.

MEB, YÖK ve İŞ-KUR'un mesleki eğitim faaliyetlerinin Mesleki Yeterlilik Kurumu ile işbirliği yapılarak özerk bir mesleki eğitim kurumu oluşturulması ve koordinasyonun sağlanması faydalı olur. Ulusal mesleki bilgi sistemi oluşturulmalıdır. Üniversitelerde bölüm ve program açılırken veya öğrenci alınırken sanayi ve hizmet sektörünün taleplerinin dikkate alınması, mezunların eğitim aldığı alanlarda çalışıp çalışmadıklarının araştırılması gerekir.

Bölgesel kalkınmada yerel dinamiklerin harekete geçirilmesi için girişimciliğin mutlak surette desteklenmesi gerekir. Girişimciliği desteklemek üzere girişimcilik eğitimine ağırlık verilmeli ve girişimci adaylarına danışmanlık sağlanmalıdır.

Endüstriye dayalı öğrenme (staj) ve işbaşında eğitim uygulamaları etkinleştirilmelidir. İşletmelerdeki staj ile öğrenci iş tecrübesi edinebilir, işverenin de eleman bulmasına ve istihdam etmesine yardımcı olur. Staj, üniversite ile işletmeler arasında bir köprü görevi görebilir. Öğrencilerin ve öğretim elemanlarının sanayide uygulama yapma imkânının geliştirilmesi gerekir.

Kalkınma ajansı, KOSGEB, TÜBİTAK ve AB kaynaklarından ve teşviklerinden yararlanabilmek amacıyla ortak proje hazırlama kültürü geliştirilmelidir.

Bölgedeki organize sanayi bölgesi yöneticileri; sanayicilerle üniversiteler arasındaki işbirliğini sağlama ve geliştirmede, sanayicilerin sorunlarını ve taleplerini üniversitelere iletme ve çözüm geliştirmede önemli görevler üstlenebilir. MYO yapımında özel sektörün yatırım yapması, özellikle organize sanayi bölgelerinde bu yatırımın yaygınlaşması gerekir.

Türkiye'nin ekonomik kalkınması, rekabet gücünün arttırılması, bölgesel kalkınma ve nitelikli insan gücünün yetiştirilmesinde, kamu üniversite sanayi 
işbirliği çok önemlidir. Nitelikli insan gücü de kaliteli mesleki ve teknik eğitimle yetiştirilebilir.

TR82 Bölgesinde üniversite sanayi işbirliğine yönelik çalışmalar olmakla birlikte, bunun sürdürülebilir ve kurumsal olması daha çok fayda sağlar. TR82 Bölgesi illerinden Çankırı' da yeni kurulan Çankırı Teknoloji Geliştirme Bölgesi ile KÜSİ çalışmalarının daha kurumsal ve güçlü hale geleceği ve bölgeye çok olumlu katkılarının olacağı düşünülmektedir.

\section{Kaynakça}

Arı, A. (2006). Bölgesel kalkınma politikaları ve yeni dinamikler. İstanbul: Derin Yayınları.

Çankırı'da Üniversite-Sanayi İşbirliği Çalıştayı Sonuç Raporu, (13 Haziran 2013). (Erişim Tarihi: 15.03.2015), http://usic.karatekin.edu.tr

Çankırı Karatekin Üniversitesi İdari Faaliyet Raporu, (Erişim Tarihi: 11.04.2017) http://strateji.karatekin.edu.tr/faaliyet-raporu-4885-sayfasi.karatekin

Dağlar, H., Durukan, T. (2011). Üniversitenin kent ekonomisine katkısı ve üniversite öğrencilerinin harcamalarının analizi. Çankırı Araştırmaları Dergisi, 6(7), 57-73.

DPT, (2013). Onuncu Kalkınma Planı (2014-2018), 06.07.2013 Tarih ve 28699 Mükerrer Sayılı Resmi Gazete, Ankara.

Erdil, E., Pamukçu, M.T., Akçomak, İ.S., Erden Y. (2013). Değişen üniversitesanayi işbirliğinde üniversite örgütlenmesi, Ankara Üniversitesi SBF Dergisi, 68(2), 95-127. DOI: http://dx.doi.org/10.1501/SBFder_0000002281

Han, E. ve Kaya, A. A. (2012). Kalkınma ekonomisi. Ankara: Nobel Yayınevi.

Kamu Üniversite Sanayi İşbirliği Portalı (KÜSİP) (Erişim Tarihi: 03.07.2018) https://kusip.gov.tr/kusip/views/hakkinda.htm

Kara, M. (2008). Bölgesel rekabet edebilirlik kavramı bölgesel kalkınma politikalarının yansımaları, Ankara: DPT Yayınları, No: 2774.

Kastamonu Üniversitesi İdari Faaliyet Raporu, (Erişim Tarihi: 15.03.2015), https://www.kastamonu.edu.tr/index.php/tr/idari-birimler/anamenu-sgdb-tr

Kuzey Anadolu Kalkınma Ajansının Kuruluşu, (Erişim Tarihi: 05.01.2018) https://www.kuzka.gov.tr/

Sakınç, S., Aybarç Bursalığlu, S. (2011). Bölgesel kalkınmada üniversite sanayi işbirliği stratejileri. Uluslararası Yükseköğretim Kongresi: Yeni Yönelişler ve Sorunlar Bildiri Kitabl, UYK- 2011, İstanbul, 2163-2169. 
Sanayinin Geliştirilmesi ve Üretimin Desteklenmesi Amacıyla Bazı Kanun ve Kanun Hükmünde Kararnamelerde Değişiklik Yapılmasına Dair Kanun, Kanun No.7033, (Erişim Tarihi: 05.12.2017)

http://www.resmigazete.gov.tr/eskiler/2017/07/20170701-21.htm

Sinop Üniversitesi İdari Faaliyet Raporu, (Erişim Tarihi: 15.03.2015), https://www.sinop.edu.tr/Strateji_Gelistirme_Daire_Baskanligi-51

Tunalı, H., Toprak, B. (2017). Dünyada ve Türkiye'de üniversite sanayi işbirliği ve yenilikçi üretim, Siyaset, Ekonomi ve Yönetim Araştırmaları Dergisi, (5)4, 237-257.

Türkiye Cumhuriyeti Bilim, Sanayi ve Teknoloji Bakanlığı 3. Sanayi Şurası Raporu, 20-22 Kasim 2013, Ankara.

T.C. Bilim Sanayi ve Teknoloji Bakanlığı OSB Bilgi Sitesi, (Erişim Tarihi: 10.04.2017), https://osbbs.sanayi.gov.tr/

Türkiye Kamu-Üniversite-Sanayi İşbirliği (KÜSI) Stratejisi ve Eylem Planı (2015-2018), (Erişim Tarihi: 29.12.2017)

https://kusip.gov.tr/kusip/yonetici/hakkindaEkGoster.htm?id=6

Türkiye İstatistik Kurumu Bölgesel İstatistikler, (Erişim Tarihi: 29.12.2017) https://biruni.tuik.gov.tr/bolgeselistatistik/

Üçler, Y.T. (2014). Bölgesel kalkınmada üniversite-sanayi işbirliğinin sanayiye devlete ve üniversiteye yararları: Konya ili özelinde bir araştırma, Dumlupınar Üniversitesi Sosyal Bilimler Dergisi, (41), 107-120.

Yıldırım, N. (2014). Üniversitelerde yenilikçilik, üniversite-sanayi işbirliği ve bölgesel kalkınma yönelimleri üzerine bir araştırma. Marmara Üniversitesi Öneri Dergisi, 11(42), 157-174. DOI: http://dx.doi.org/10.14783/od.v11i42.5000065512 


\title{
Public University Industry Cooperation and Regional Development -TR82 Region Example
}

\author{
Extended Abstract
}

\section{Introduction}

Well-trained and skilled manpower plays a major role for a country's growth and development. Skilled labor that industry and service sectors needs will be grown with vocational and technical education. Thus, the international competitive power will be increased and the country's economic development will be accelerated.

Turkey is obliged to train the needed information era manpower to raise the national competition level, to have a voice in the international market and to integrate with European Union. Therefore, it is very important to establish a realistic cooperation between the business world and universities.

The main task of the universities is research and education, as well as creating, preserving, sharing and using knowledge for the benefit of society. On the other hand, Industry uses knowledge in a practical way and transforms it into product. In the information society where everything is changed and renewed very rapidly university industry cooperations are also changing (Erdil, Pamukçu ve Akçanak, 2013, s. 95).

Mechanisms to be used for university-industry cooperation: The Scientific And Technological Research Council of Turkey (TÜBİTAK) and Small And Medium Business Development And Support Administration (KOSGEB) projects related to the industry, continuing training centers, industrial visits, research and application centers, works on the revolving fund, cooperation with development agencies and industry-based learning (internship) studies.

\section{Method}

The goal of this study is to examine the studies about public university industry cooperation and to investigate the relations of these studies with regional development. This paper covers the effects of the university-industry cooperation to regional development in TR82 region that includes Çankırı, Kastamonu and Sinop.

To determine the current situation and recommendations by utilizing the public open sources of universities, the chambers of trade and industry, provincial directorates for science, technology and industry and regional development agency in TR82 region. Public University industry cooperation (KÜSI) studies in the TR82 region, it started with the preparation T.R of the Ministry of Science Industry and Technology's KÜSİ Strategy and Action Plan in 2013.

Kastamonu University 2006, Çankırı Karatekin and Sinop University were established in 2007 in the TR82 region, but there have been significant increases in the number of students and academic staff. The number of academic staff of Kastamonu University has increased continuously in the years we have examined. There has been a continuous increase in the number of academic staff except 2016 for Çankırı Karatekin University and 2012 for Sinop University. When the year 2012 is passed to 2013, there has been a higher increase percentage the number of academic staff of Çankırı Karatekin and Sinop Universities. It can be said that this increase is the effect of the KÜSI studies. Academic staff can make a positive contribution to the KÜSİ by their scientific researches, R\&D studies and projects.

Unemployment rate in the TR82 Region appears to be under the Turkey unemployment rate in the years between 2009 and 2016. The rate of unemployment in the TR82 region after 2013 has been continuously decreasing. 


\section{Results and Discussion}

TR82 region has an economic structure predominantly agricultural. While Turkey's average share in the gross value added of agriculture sector is 9.0 percent, this region is 23.0 percent. However, industrialization efforts in the region are noteworthy. It is thought that a positive effect of the KÜSİ on the increase in the share of industry in the gross domestic product of the region.

Establishment dates of universities are new in the TR82 region, Kastamonu 2006, Çankırı and Sinop 2007. It has been observed that with the establishment of universities, the numbers of academic units, academic and administrative personnel and students have increased rapidly. While the total number of academic staff in Turkey in 2015 compared to 2008 increased by 55\%, 399\% increase has been in the region. Especially in 2013, the leaping in the number of university academic staff in the region can be said to be a positive effect of KǗSI.

After 2013 the difference between the unemployment rate in Turkey and unemployment rate of the TR82 region are increased also, KÜSİ has impacted the reduction of unemployment in the region.

As a result of university-industry cooperation; university graduates find jobs and employment opportunities, contribute to regional development, students are given the opportunity to gain industrial experience with internships. Industrialists can increase their research and development opportunities, can benefit from the university's lifelong learning centers and can choose human resources to be employed.

\section{Conclusion}

Courses can be opened and trainings can be provided in the fields that the industrialists need through continuous education center, lifelong learning, distance education centers in the university. Industrial workers can be encouraged to pursue postgraduate studies in their fields. Cooperation can be made with the industrialists in the related fields of the industry to the determination of master and doctoral thesis subjects.

Managers of organized industrial estates in the region; they may take important tasks to provide and develop cooperation between industrialists and universities, to communicate industrialists' problems and demands to universities and to develop solutions. The investment of the private sector is necessary for the construction of the vocational and technical college; especially this investment should be widespread in organized industrial areas.

There are efforts for university industry cooperation in the region TR82 where the North Anatolian Development Agency operates. It can be said that the universities in these provinces have contributed greatly to the development of the region with the number of students, academic and administrative staff. There has been determined an increase academic staff number and the unemployment rate in the region found to be below the Turkey level after public universityindustry cooperation activities.

Although there are studies on university industry cooperation in the TR82 region, it is more beneficial to be sustainable and institutionalized. When the Technology Development Zones are established, the KÜSİ studies will become more institutional and stronger and will have a very positive contribution to the region in the TR82 region. 